\title{
Single cell protein production using low quality fruits of some dates
}

\author{
Sorour M. A. ${ }^{\text {, }}$ Ramadan B. R. ${ }^{\text {, }}$, Mehanni A. E. ${ }^{a^{*}}$, Abd-Elkarim Naglaa ${ }^{\mathrm{c}}$ \\ ${ }^{a}$ Food Science and Nutrition Department, Faculty of Agriculture, Sohag University, Sohag, Egypt \\ ${ }^{b}$ Food Science and Technology Department, Faculty of Agriculture, Assiut University, Assiut, Egypt \\ ${ }^{c}$ Food Science and Dairy Department, Faculty of Agriculture, South Valley University, Qena, Egypt
}

\begin{abstract}
Single cell protein (SCP) is a good source of essential amino acids. This study aimed to utilize some date byproducts such as date fruit flesh to produce single cell protein. Fruit flesh of three unknown dates and three date varieties were used to produce a single cell protein by Saccharomyces cerevisiae ATCC64712 under different condition (sugar concentrations in the extract media, temperatures and $\mathrm{pH}$ values). The results showed that the optimum production of the biomass $(42.85 \mathrm{~g} / \mathrm{l})$ was produced from date extracts media at $18 \%$ sugar, $30^{\circ} \mathrm{C}$ and $\mathrm{pH}$ 4.5. To reduce nucleic acids content in the biomass, heat shock was used. The effect of heat shock on protein content and nucleic acids percentage for the studied yeast strain was $75.83 \%$, and the maximum reduction of nucleic acids was observed at $\mathrm{pH} 4$ and $60^{\circ} \mathrm{C}$ for $30 \mathrm{sec}$ with $20.88 \%$ loss of its protein content. The present study provides evidence that date flesh is a great source for single cell protein that can be used in variable fermentations. Additionally, single cell protein has a high level of essential amino acids such as lysine, methionine and threonine. This source of protein has been proved a good replacement of other expensive protein sources like fish and soybean meals. Therefore, conclusion can be made that single cell protein can easily replace traditional (plant and animal) protein sources in human, animal as well as fish diets without any detrimental effect.
\end{abstract}

Keywords: single cell protein, date fruit, Saccharomyces cerevisiae, amino acids. 


\section{Introduction}

The date palm (Phoenix dactylifera L.) is one of the most economically important fruit tree grown in Egypt. Production of Egypt alone represent about $20 \%$ of the total world production at 2012 (Bekheet, 2013; FAO, 2018).There were a gradually increase in the worldwide production; it was about 8.5 million tons in 2016. About half of date production is wasted and thus unutilized. Dates are rich in certain nutrients and provide a good source of rapid energy due to their high carbohydrates content $(70-80 \%)$. Most of the carbohydrates in date fruits are in the form of fructose and glucose, which are easily absorbed by the human body (AlFarsi et al., 2005; 2008; Mrabet et al., 2008). Date seed oil has been used to replace the portions of other vegetable oils in body creams, shampoos, and shaving soap formulations, and, in general, the quality of these cosmetic formulations is encouraging (Devshony et al., 1992). Besides, date seed has also been introduced recently to the market as a coffee substitute (Rahman et al., 2007). Almost half of the sugar in dates is fructose; and over $75 \%$ of dates are reduced sugars on dry basis. Thus, date is a prospective raw material for the production of fructose and single cell protein (Lattieff, 2016). To reduce the production cost of single cell proteins, the most important thing is the selection of cheap and suitable substrates or biodegradable agro industrial byproducts as a nutrient source for the microorganisms to grow and produce tons of protein (Anupama and Ravindra, 2000). For this purpose, different substrates were used and compared in the past. Some of the commonly used substrates are apple pomace, yam peels, citrus pulp, potato peels, pineapple waste, papaya waste etc. (Nasseri et al., 2011). It is also very important to choose suitable waste product for the proliferation of single cell protein producing microorganism. Nowadays, for both research and industrial purpose, availability of microorganisms is not an issue as many strains of bacteria, algae, fungi and yeast can be cultured in the laboratory by different ways. Mainly, microorganisms do not depend on substrate properties with exception of few. However, substrate availability is very limited regarding the consumer and concerned economy (Ferreira et al., 2010). The aim of this study was to optimization condition of single cell protein production.

\section{Materials and methods}

\subsection{Materials}

\subsubsection{Date samples}

This study was carried out on low quality date fruits of three of unclassified dates (Manthour or seedling) called Mt.1, Mt.2 and Mt.3, and three classified date include Hayany and Zaghloul (soft varieties) and Saidy (semi dry date variety). The unclassified (Manthour, Mt.) date fruits called Mt.1, Mt.2 and Mt.3. Date fruits of Hayany, Zaghloul, Mt.1 and Mt.2 were obtained from Qena governorate, Egypt while, Saidy and Mt.3 fruits obtained from El-Kharja Date Packing Factory, ElKharja oasis, The New Valley governorate, Egypt during the 2013 
seasons (Figure 1).

\subsubsection{Yeast strain}

Saccharomyces cerevisiae

ATCC64712

Microbiological

obtained

(MIRCEN), Ain

Egypt.

\subsubsection{Media for yeast}

Glucose peptone yeast extract medium

EMCC from

Resources Center Shams University,

was used for yeast maintenance composition is follows DSM Medium 186 (Yeast extracts $3 \mathrm{~g}$, glucose $10 \mathrm{~g}$, peptone from soybeans $5 \mathrm{~g}$, agar $15 \mathrm{~g}$, malt extracts $3 \mathrm{~g}$, distilled water $1000 \mathrm{ml}$ ).
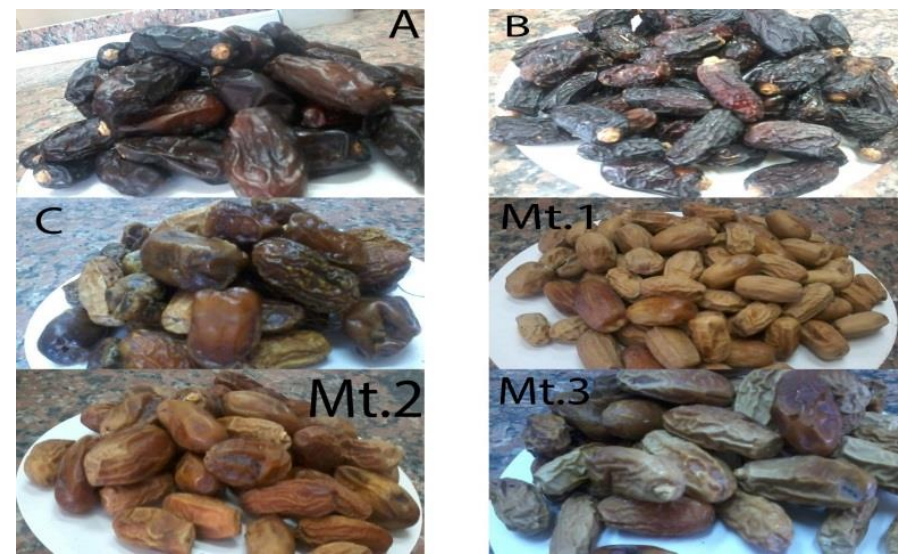

Figure (1): Morphological picture of the studied date samples: A (Hayany), B (Zaghloul), C (Saidy), Mt1, Mt2 and M3 (Manthour).

\subsection{Single cell protein production}

\subsubsection{Preparation of date juice}

The mixture of six date fruits was cleaned from extraneous materials then washed and the pits were removed. The date flesh was cut into small pieces to decrease their size in order to improve the extraction efficiency. The small pieces of flesh were mixed with water ( 1 flesh: 4 water, w/v) and soaked for $12 \mathrm{hr}$ under cooling, boiled gently for $30 \mathrm{~min}$, then blended in an electric mixer (Blinder) for one minute and the date fruit juice filtered through double fold cheese to exclude all large undigested particles. Date juice was packaged in double polyethylene bags and kept at $-15^{\circ} \mathrm{C}$ till further experiments. The date fruit juice was prepared from date mixture (Shubbar, 1981) as illustrated in Figure (2).

\subsubsection{Effect of environmental factors}

The most environmental conditions were studied to produce the highest biomass and protein content from the tested yeast 
strain as follows:

- The $\mathrm{pH}$ value: Date juice medium was adjusted at different $\mathrm{pH}$ values ranged from 3.5 to $6.0 \mathrm{pH}$. Flasks of different $\mathrm{pH}$ levels were incubated at $30^{\circ} \mathrm{C}$ for $96 \mathrm{hr}$ on rotary shaker at $150 \mathrm{rpm}$.

- Temperature: Flasks containing date juice media with $18 \%$ sugar content were adjusted to $\mathrm{pH} 4.5$ and incubated at different temperatures; $25,30,35$ and $40^{\circ} \mathrm{C}$ for $96 \mathrm{hr}$ using rotary shaker at $150 \mathrm{rpm}$.

- Inoculum size: Suspension of cell obtained from yeast strain was used as inoculum size in a range between $1-6 \%(0.5$ to $3.0 \mathrm{ml})$ inoculum. The inoculated flasks contained $50 \mathrm{ml}$ media were incubated at $30^{\circ} \mathrm{C}$ on rotator 150 $\mathrm{rpm}$ for $48 \mathrm{hr}$. Biomass production using fermenter incubation period at optimal condition, however yeast strain incubated in date juice medium three liter in fermenter at aeration rate $2.51 / \mathrm{min}, \mathrm{pH} 4.5$ and $30^{\circ} \mathrm{C}$ for $96 \mathrm{hr}$. Biomass, crude protein (CP) and total crude protein (TCP) were determined.

\subsubsection{The dried yeast cells}

The produced yeast cells were harvested by centrifugation at $3000 \mathrm{rpm}$ for $15 \mathrm{~min}$. The supernatant was then decanted and the residual cell suspended in distilled water and re- centrifugation. This was repeated twice. Finally, the cells were transferred to measuring flask (100) using distilled water. Aliquots of $5 \mathrm{ml}$ were taken and dried at $105^{\circ} \mathrm{C}$ overnight and results were given as $\mathrm{g}$ dried yeast per litre of the used medium (Kishan and Neelakantan, 1989; White, 1954).

\subsubsection{Yeast biomass}

The biomass of yeast strain was centrifuged, washed twice with distilled water and dried at $70^{\circ} \mathrm{C}$ till constant weight was obtained.

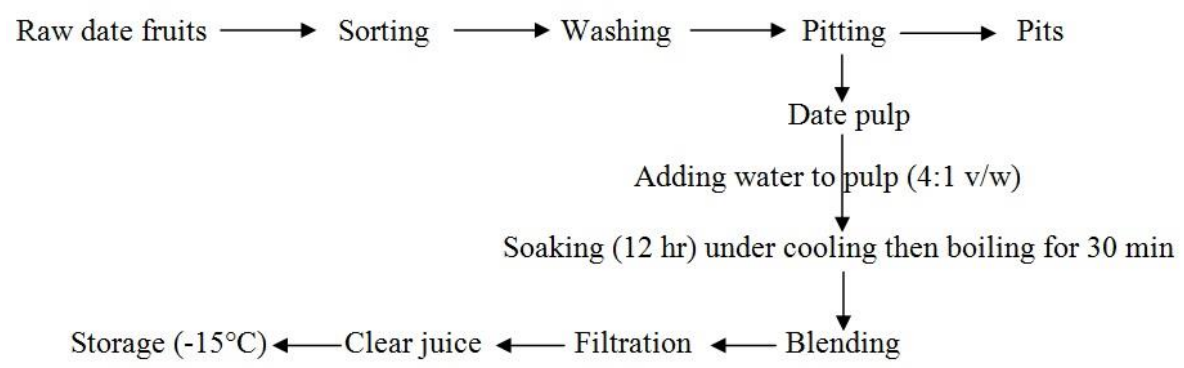

Figure (2): Extraction of date juice flow diagram. 


\subsubsection{Total soluble solids (TSS)}

Total soluble-solids values as brix were determined with Digital Refract meter (Model no. RX 5000, ATAGO, Japan) at $25^{\circ} \mathrm{C}$.

\subsubsection{The $\mathrm{pH}$ value}

The $\mathrm{pH}$ values were measured using digital $\mathrm{pH}$ meter model no. APX 175, Control Dynamics Ltd., Bangalore, India.

\subsubsection{Crude protein and amino acids}

The nitrogen content was analyzed using the standard Kjeldahl procedure (AOAC, 2016). Protein content was calculated by multiplying the nitrogen content by 6.25 according to Merrill and Watt (1973). Amino acids were determined using Automatic Amino Acid Analyzer (AAA 400INGOS Ltd). Total amino acids hydrolysis was carried out according to the method of Csomós and Simon-Sarkadi (2002). Free amino acids extraction was carried out according to the method of Shalabia (2011).

\section{Results and Discussion}

\subsection{Production of single cell protein}

\subsubsection{Environmental conditions}

Saccharomyces cerevisiae EMCC ATCC64712 utilize the available wastes and use them as growth medium to increase their cell masses which are made up of the SCP. Fermentation is the main process responsible for SCP production. After the completion of the fermentation process, the available biomass is harvested which can further be utilized as a protein source. Then this source undergoes further processing techniques like purification, cell disruption, washing followed by protein extraction to give generally high production rates along with better yield and makes the production control relatively easier. The most important variables affecting the cultivation and production of SCP are the environmental conditions under which the microorganisms were cultivated (incubation temperature, $\mathrm{pH}$ value, incubation period, inoculums size and composition of the growth medium) (Kishan and Neelakantan, 1989).

\subsubsection{Effect of $p H$ value}

Extracts of date fruits containing $18 \%$ sugar, adjusted to different $\mathrm{pH}$ values such as 3.5, 4.0, 4.5, 5.0, 5.5 and 6.0 were used to produce single cell protein by the selected yeast. Results in Table (1) showed that the slightly acidic $\mathrm{pH}$ (3.56.0) was appropriate for biomass production by the $S$. cerevisiae ATCC 64712. The maxima of biomass, crude protein $(\mathrm{CP})$ and total crude protein (TCP) were obtained at $\mathrm{pH} 4.5$ followed by $\mathrm{pH}$ 5.0. The maxima production of biomass $(42.85 \mathrm{~g} / \mathrm{l})$, crude protein $\mathrm{CP}(67.8 \%)$ and total crude protein TCP $(29.05 \mathrm{~g} / \mathrm{l})$ were obtained at $\mathrm{pH} 4.5$ followed by $32.45 \mathrm{~g} / \mathrm{l}$, $60.18 \%$ and $19.52 \mathrm{~g} / \mathrm{l}$, respectively at $\mathrm{pH}$ 5.0. This finding was supported by the 
suggestion that a weak acidic medium is more appropriate for the overall growth of yeasts (Pramanik, 2003). The results are agree with those obtained by Abou-Aly (1996) and Hassan (2012). They found that the biomass and total crud protein were gradually increased by increasing $\mathrm{pH}$ up to 4.5. However, other observations suggest that the $\mathrm{pH}$ range of any yeast strain could vary depending on the medium composition. In this context, Onishi (1963), and Kishan and Neelakantan, (1989) showed that the $\mathrm{pH}$ range for the growth of $Z$. Rouxii strain isolated from the soy sauce process without $\mathrm{NaCl}$ was very broad $(\mathrm{pH} 3.0$ 7.0), while in a medium containing $18 \%$ $\mathrm{NaCl}$, the $\mathrm{pH}$ range for growth was narrow (pH 4.0-5.0). Data of statistical analysis of biomass (Table 1) showed that there were high significant differences among biomass, $\mathrm{CP}$ and TCP produced by yeast strain at $\mathrm{pH} 4.5$ and at the other $\mathrm{pH}$ values with the same conditions. On the other hand, there were no significant differences among biomass and $\mathrm{CP}$ production at $\mathrm{pH} 4.0,5.0$ and 5.5, and among TCP at $\mathrm{pH} 5.0$ and 5.5.

Table (1): Effect of initial medium $\mathrm{pH}$ on biomass production and protein content of Saccharomyces cerevisiae ATCC 64712.

\begin{tabular}{|l|l|l|l|}
\hline Initial pH & Biomass g/l & CP \% & TCP g/l \\
\hline 3.5 & $28.07^{\mathrm{c}} \pm 0.043$ & $42.00^{\mathrm{d}} \pm 0.15$ & $11.79^{\mathrm{e}} \pm 0.30$ \\
\hline 4.0 & $31.94^{\mathrm{b}} \pm 0.54$ & $58.0^{\mathrm{b}} \pm 0.154$ & $18.51^{\mathrm{c}} \pm 0.06$ \\
\hline 4.5 & $42.85^{\mathrm{a}} \pm 0.164$ & $67.8^{\mathrm{a}} \pm 0.06$ & $29.05^{\mathrm{a}} \pm 0.100$ \\
\hline 5.0 & $32.45^{\mathrm{b}} \pm 0.259$ & $60.18^{\mathrm{b}} \pm 0.748$ & $19.52^{\mathrm{b}} \pm 0.089$ \\
\hline 5.5 & $32.00^{\mathrm{b}} \pm 0.66$ & $59.46^{\mathrm{b}} \pm 0.308$ & $19.02 \mathrm{~b}^{\mathrm{c}} \pm 0.355$ \\
\hline 6.0 & $27.60^{\mathrm{c}} \pm 0.398$ & $45.60^{\mathrm{c}} \pm 0.396$ & $12.57^{\mathrm{d}} \pm 0.087$ \\
\hline LSD & 1.249 & 2.347 & 0.627 \\
\hline
\end{tabular}

\subsubsection{Effect of incubation temperature}

Samples of date extracts were adjusted to 20 brix (18\% sugar concentration) and $\mathrm{pH}$ 4.5 , then inoculated with yeast and maintained for produced single cell protein at $25,30,35$ and $40^{\circ} \mathrm{C}$. The optimum temperature for single cell protein production by $S$. cerevisiae ATCC 64712 after $60 \mathrm{hr}$ with standard inoculum grown in sugar date juice (18\%) are shown in Table (2). Results showed that $S$. cerevisiae ATCC 64712 strains was able to grow up to $40^{\circ} \mathrm{C}$. The maximum yield was $42.85 \mathrm{~g} / \mathrm{L}$ at $30^{\circ} \mathrm{C}$ and decreased to $16.51 \mathrm{~g} / 1$ at $40^{\circ} \mathrm{C}$. These results demonstrated the $30^{\circ} \mathrm{C}$ was the optimum degree for biomass production, crude protein and total crude protein. Based on the information available in the literature, the optimum temperature varies widely among the yeast strains, that $28^{\circ} \mathrm{C}$ is the most favorable temperature for biomass production by Kluyveromyces lactis grown on whey permeate. Lee et al. (1993) reported that the optimum 
temperature for thermo-tolerant Candida tropicalis used for SCP production was 38 ${ }^{\circ} \mathrm{C}$. Rajoka, (2004)) and Rajoka et al. (2006) studied the production of SCP by Candida utilis at different temperatures $\left(20-45^{\circ} \mathrm{C}\right)$ in a stirred fermenter and reported that the maximum production of $\mathrm{CP}$ was realized when the fermentation temperature was maintained at $35^{\circ} \mathrm{C}$. They also found that the production of $\mathrm{CP}$ decreased above $35^{\circ} \mathrm{C}$. High temperature can cause inactivation of enzymes of the metabolic pathway, while low temperature may not permit the flow of nutrients across the cell membrane, resulting in a high demand for maintenance energy. However, at low temperature, the enzyme activities are expectedly low (Converti and Dominguez, 2001; Roels, 1983). From statistical analysis, data provided that there were high significant difference among biomass, $\mathrm{CP}$ and $\mathrm{TCP}$ produced by yeast strain at $30^{\circ} \mathrm{C}$ and other produced at different temperatures used except in between 25 and $35^{\circ} \mathrm{C}$, there was no significant difference in biomass produced by yeast.

Table (2): Effect of incubation temperature on biomass production and protein content of Saccharomyces cerevisiae ATCC 64712.

\begin{tabular}{|l|l|l|l|}
\hline Incubation temperature ${ }^{\circ} \mathrm{C}$ & Biomass g/l & CP \% & TCP g/l \\
\hline 25 & $41.36^{\mathrm{b}} \pm 0.29$ & $51.71^{\mathrm{c}} \pm 0.053$ & $21.29^{\mathrm{c}} \pm 0.203$ \\
\hline 30 & $42.85^{\mathrm{a}} \pm 0.16$ & $67.8^{\mathrm{a}} \pm 0.05$ & $29.05^{\mathrm{a}} \pm 0.10$ \\
\hline 35 & $42.4^{\mathrm{ab}} \pm 0.14$ & $62.57^{\mathrm{b}} \pm 0.057$ & $26.52^{\mathrm{b}} \pm 0.083$ \\
\hline 40 & $16.51^{\mathrm{d}} \pm .811$ & $49.6^{\mathrm{d}} \pm 0.58$ & $8.17^{\mathrm{d}} \pm 0.31$ \\
\hline LSD & 1.456 & 0.955 & 0.636 \\
\hline
\end{tabular}

\subsubsection{Effect of inoculum size}

Samples of date extracts were adjusted to 20 Brix (18\% sugar concentration), 4.5 $\mathrm{pH}, 30^{\circ} \mathrm{C}$ and inoculated with suspension of yeast cells obtained from active slants prepared to study the effect of inoculum size, which were used in range between 1$6 \%(0.5-3.0 \mathrm{ml}$ inoculum medium) on biomass production. Table (3) showed that the biomass, CP and TCP gradually increased with the inoculum size increasing to the maximum $(42.85 \mathrm{~g} / \mathrm{l}$, $67.8 \%$ and $29.05 \mathrm{~g} / \mathrm{l}$, respectively) at the inoculum 5\%. These results are agreement with Alian et al. (1990), Francisco et al. (2010) and Hassan (2012). They reported that the best ratio of inoculum size for single cell protein production of Saccharomyces cerevisiae was 5\% v/v. Statistically, it was clear that there were high significant differences among biomass and TCP produced by yeast strain at all inoculum except in between 1.5 and 3.0 inoculum size. On the other hand, data also revealed that there was no significant difference in between 1.0 and 3.0 inoculum size in CP production. 
Table (3): Effect of inoculum size on biomass and protein content of Saccharomyces cerevisiae ATCC 64712.

\begin{tabular}{|l|l|l|l|l|}
\hline \multicolumn{2}{|l|}{ Inoculum size } & \multirow{2}{*}{ Biomass g/l } & \multirow{2}{*}{ CP $\%$} & \multirow{2}{*}{ TCP g/l } \\
\cline { 1 - 2 } $\mathrm{ml}$ & $\%$ & & & \\
\hline 0.5 & 1 & $32.09^{\mathrm{e}} \pm 0.57$ & $45.46^{\mathrm{e}} \pm 0.57$ & $14.57^{\mathrm{e}} \pm 0.07$ \\
\hline 1.0 & 2 & $35.2^{\mathrm{d}} \pm 0.57$ & $54.54^{\mathrm{d}} \pm 0.56$ & $19.18^{\mathrm{d}} \pm 0.11$ \\
\hline 1.5 & 3 & $37.60^{\mathrm{c}} \pm 0.58$ & $56.54^{\mathrm{c}} \pm 0.58$ & $21.24^{\mathrm{c}} \pm 0.10$ \\
\hline 2.0 & 4 & $40.50^{\mathrm{b}} \pm 0.57$ & $65.16^{\mathrm{b}} \pm 0.58$ & $26.38^{\mathrm{b}} \pm 0.32$ \\
\hline 2.5 & 5 & $42.85^{\mathrm{a}} \pm 0.16$ & $67.8^{\mathrm{a}} \pm 0.05$ & $29.05^{\mathrm{a}} \pm 0.10$ \\
\hline 3.0 & 6 & $38.70^{\mathrm{c}} \pm 0.58$ & $53.73^{\mathrm{d}} \pm 0.44$ & $20.78^{\mathrm{c}} \pm 0.15$ \\
\hline LSD & 1.63 & 1.55 & 0.52 \\
\hline
\end{tabular}

\subsubsection{Effect of sugar concentration}

The suitability of date extracts containing different sugar concentrations to produced single cell protein by $S$. cerevisiae ATCC 64712 was studied (Table 4). The tested sugar concentrations in date extract were $10,12,14,20,22$ and $24 \%$. Results in Table (4) illustrated that concentration of the date juice significantly affected the productivity of biomass and crude protein of the yeast. The biomass and $\mathrm{CP}$ increased with the increase in concentration of the substrate up to $18 \%$. The maximum production of biomass and $\mathrm{CP}$ were recorded when the yeast grown in $18 \%$ sugar of date juice after $60 \mathrm{hr}$ at $30^{\circ} \mathrm{C}$ and $4.5 \mathrm{pH}$. However, when the sugar concentration of substrate increased up to $20 \%$, the biomass and CP of the yeast strains decreased by 20.91 and $16.62 \%$, respectively. These results proved that $18 \%$ sugar in date juice is the most appropriate concentration to encourage the growth and production of the biomass by the yeast strain. They seemed to carry out all normal physiological processes in a moderate concentration of sugars, while the increase in date juice concentration slowed down their growth. The decrease in growth rate in high concentrations of date juice could be attributed to the viscosity of the medium and plasmolysis of yeast cells that retard or stop their growth (Pramanik, 2003). In similar studies, Hashem et al. (2014) optimized the cultural conditions for production of single-cell protein by yeast strains (Zygosaccharomyces rouxii KKUY-0157 and Hanseniaspora uvarum KKUY0084) spoilage date juice (SDJ). They showed the best growth and production of biomass at $25{ }^{\circ} \mathrm{C}$ in a $20 \%$ date juice concentration, they could resist an increase in temperature to $30{ }^{\circ} \mathrm{C}$, and they could grow in higher concentrations of date juice. They noticed that the growth and biomass productivity of the two strains were greatly enhanced by adding metals such as $\mathrm{Mn}$ or $\mathrm{Mg}$ as well as a nitrogen source (tryptone). Data given in Table (4) indicated that there were high significant differences in the biomass production in all used sugar concentration except inbetween 16, 22 and 24\% sugar. 
Table (4): Effect of sugar concentration on biomass production and protein content of Saccharomyces cerevisiae ATCC 64712.

\begin{tabular}{|l|l|l|l|}
\hline Sugar concentration (\%) & Biomass g/l & CP \% & TCP g/l \\
\hline 10 & $22.93^{\mathrm{f}} \pm 0.672$ & $44.3^{\mathrm{h}} \pm 0.057$ & $10.15^{\mathrm{g}} \pm 0.29$ \\
\hline 12 & $24.96^{\mathrm{e}} \pm 0.49$ & $44.8^{\mathrm{g}} \pm 0.058$ & $11.18^{\mathrm{f}} \pm 0.20$ \\
\hline 14 & $27.49^{\mathrm{d}} \pm 0.017$ & $56.32^{\mathrm{d}} \pm 0.005$ & $15.47^{\mathrm{d}} \pm 0.008$ \\
\hline 16 & $31.3^{\mathrm{c}} \pm 0.09$ & $64.61^{\mathrm{b}} \pm 0.005$ & $20.21^{\mathrm{b}} \pm 0.060$ \\
\hline 18 & $42.85^{\mathrm{a}} \pm 0.16$ & $67.8^{\mathrm{a}} \pm 0.05$ & $29.05^{\mathrm{a}} \pm 0.10$ \\
\hline 20 & $33.62^{\mathrm{b}} \pm 0.18$ & $56.53^{\mathrm{c}} \pm 0.005$ & $19.00^{\mathrm{c}} \pm 0.11$ \\
\hline 22 & $31.35^{\mathrm{c}} \pm 0.12$ & $46.83^{\mathrm{e}} \pm 0.05$ & $14.64^{\mathrm{e}} \pm 0.03$ \\
\hline 24 & $31.28^{\mathrm{c}} \pm 0.16$ & $45.6^{\mathrm{f}} \pm 0.008$ & $14.26^{\mathrm{e}} \pm 0.07$ \\
\hline LSD & 0.954 & 0.107 & 0.423 \\
\hline
\end{tabular}

Also, there were high significant differences in $\mathrm{CP}$ between all used sugar concentrations. Besides, there was high significant difference in TCP except among 22 and $24 \%$ sugar concentration. Furthermore, Table (5) and Figure (3) were illustrated the amino acid composition of the protein hydrolysate of Saccharomyces cerevisiae ATCC 64712. Data revealed that fifteen amino acids were detected and identified. Aspartic acid (Asp) was the predominant amino acid (16.37 g /100 g), followed by glutamic acid $(12.54 \mathrm{~g} / 100 \mathrm{~g})$, histidine $(9.72 \mathrm{~g} / 100 \mathrm{~g})$, alanine $(8.97 \mathrm{~g} / 100 \mathrm{~g})$ and isoleucine $(8.76 \mathrm{~g} / 100 \mathrm{~g})$. While, methionine had the lowest value $(0.62 \mathrm{~g}$ $/ 100 \mathrm{~g}$ ). Regarding the determined concentrations of the S. cerevisiae (ATCC 64712) amino acids it was contained over levels of all amino acid except methionine and leucine than those reported by Hassan (2012) in the S. cerevisiae. He found that asparatic acid 6.55, threonine 3.06, alanine 4.56 , methionine 0.67 , isoleucine 3.09, leucine 5.01, tyrosine 2.17, phenylalanine 2.57 , histidain 1.76 , lysine 4.59, glutamic acid 10.10, valine 3.72, cystine 2.00 and arginine $2.74 \mathrm{~g} / 100 \mathrm{~g}$ protein. The differences in amino acids concentration may be due to the yeast used and the mediums of growth.

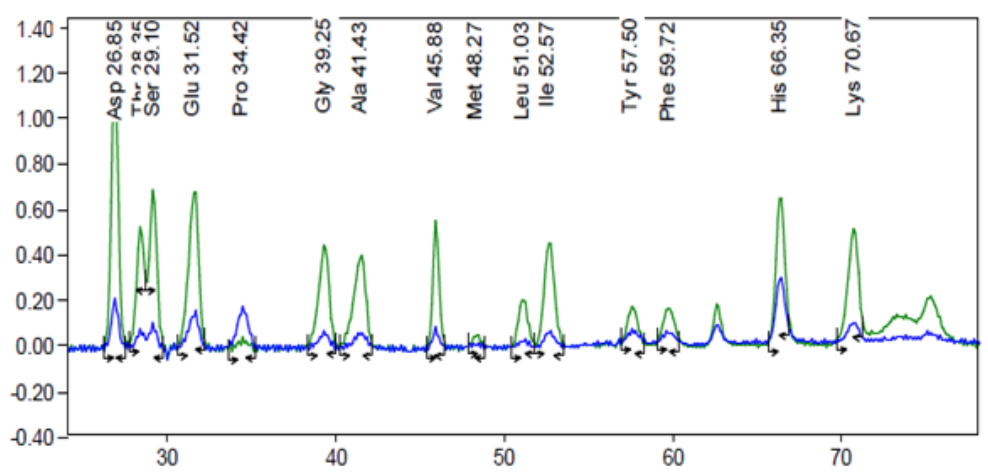

Figure (3): Amino acid content of Saccharomyces cerevisiae ATCC 64712). 
Table (5): Amino acid content of Saccharomyces cerevisiae (ATCC 64712).

\begin{tabular}{|l|l|l|l|}
\hline Peak No. & Area & Amino acid & Total acids (\%) \\
\hline 1 & 35.62 & Aspartic acid & 16.37 \\
\hline 2 & 8.16 & Threonine & 3.75 \\
\hline 3 & 12.98 & Serine & 5.97 \\
\hline 4 & 27.28 & Glutamic acid & 12.54 \\
\hline 5 & 1.82 & Proline & 0.84 \\
\hline 6 & 18.43 & Glycine & 8.47 \\
\hline 7 & 19.52 & Alanine & 8.97 \\
\hline 8 & 14.08 & Valin & 6.47 \\
\hline 9 & 1.35 & Methionine & 0.62 \\
\hline 10 & 7.99 & Leucine & 3.67 \\
\hline 11 & 19.07 & Iso Leucine & 8.76 \\
\hline 12 & 5.80 & Tyrosine & 2.67 \\
\hline 13 & 5.77 & Phenylalanine & 2.65 \\
\hline 14 & 21.14 & Histidin & 9.72 \\
\hline 15 & 18.58 & Lysine & 8.54 \\
\hline
\end{tabular}

\section{Conclusion}

From the obtained results, it could be concluded that date flesh was suitable material for single cell protein production by yeast strain; Saccharomy cescerevisiae ATCC64712. In addition, the maximum production of biomass and $\mathrm{CP}$ were recorded when the yeast grown in $18 \%$ sugar of date juice after $60 \mathrm{hr}$ at $30^{\circ} \mathrm{C}$ and $4.5 \mathrm{pH}$.

\section{References}

Abou-Aly, H. E. (1996), Microbiological studies on protein production by microorganism, Ph.D. Thesis, Department of Agricultural Botany, Faculty of Agriculture, Moshtohor, Zagazig University (Benha Branch), Egypt.

Al-Farsi, A. M., Alasalvar, C., Al-Abid, M., Al-Shoaily, K., Al-Amry, M. and
Al-Rawahy, F. (2008), "Compositional and functional characteristics of dates, syrups and their by-products ", Food Chemistry, Vol. 104, pp. 943-94.

Al-Farsi, A. M., Alsalvar, C., Morris, A., Baron, M. and Shahidi, F. (2005), "Compositional and sensory characteristics of three native sundried date (Phoenix dactylifera L.) varieties grown in Oman", Journal of Agricultural and Food Chemistry, Vol. 53, 7586-7591.

Alian, A. N., El-Masry Hoda, G., ElShimi Nagwa, M. and Fadel, M. A. (1990), "Utilization of pea peels sugar hydrolyzate in yeast protein production", Annals of Agricultural Sciences, Vol. 35 No. 1, pp. 157-166.

Anupama and Ravindra, P., (2000), "Value-added food: single cell protein", Biotechnology Advances, $18,459-479$. 
AOAC (2016), Official methods of analysis association of official Agricultural chemists, $17^{\text {th }}$ Edition, The Association of Official Analytical Chemists, Washington, D.C., USA.

Bekheet, S. (2013), "Date palm biotechnology in Egypt", Applied Science Reports, Vol. 3, pp. 44-152.

Converti, A. and Dominguez, J. M. (2001), "Influence of temperature and $\mathrm{pH}$ on xylitol production from xylose by Debarryomyces hansenii", Biotechnology and Bioengineering, Vol. 75, pp. 39-45.

Csomós, E. and Simon-Sarkadi, L. (2002), Characterisation of tokaj wines based on free amino acid and biogenic amine using ion exchange chromatography. Chromatographia, Vol. 56, pp. S185-S188.

Devshony, S., Eteshola, A. and Shani, A. (1992), "Characteristics and some potential application of date palm (Phoenix dactylifera L.) seeds and seed oil", Journal of the American Oil Chemists' Society, Vol. 69, pp. 595-597.

\section{FAO (2018), Statistical Databases, http://faostat.fao.org, accessed March 07, 2021.}

Farncisco, C., Karina, M., Laura, F., Eduarado, B. and Edurdo, D. (2010), "Effect of Saccharomyces cerevisiae inoculum size on wine fermentation aroma compounds and its relation with assimilable nitrogen content",
International Journal of Food Microbiology, Vol. 143, pp. 81-85.

Ferreira, I. M. P. L. V. O., Pinho, O., Vieira, E. and Tavarela, J. G. (2010), "Brewer's Saccharomyces yeast biomass: characteristics and potential applications", Trends in Food Science \& Technology, Vol. 21, pp. 77-84.

Hashem, M., Hesham, A. E., Alamri, S. A. and Alrumman, S. A. (2014), "Production of single-cell protein from wasted date fruits by Hanseniaspora uvarum KKUY0084 and Zygo saccharomyces", Annals of Microbiology, Vol. 64, pp. 1505-1511.

Hassan, M. A. A. (2012), Evaluation of some yeast strain for single cell protein production, M.Sc. Thesis, Department of Agricultural Botany, Faculty of Agriculture, Moshtohor, Zagazig University (Benha Branch), Egypt.

Journal of Cleaner Production, Vol. 139, pp. 1191-5.

Kishan, S. S. and Neelakantan, S. (1989), "Amino acid composition of yeast single cell protein grown on paneer whey", Journal of Dairy Research, Vol. 56, pp. 813-815.

Lattieff, F. A. (2016), "A study of biogas production from date palm fruit wastes",

Lee, C., Yamakawa, T., Kodama, T. (1993), "Rapid growth of thermo 
tolerant yeast on palm oil", Biotechnology, Vol. 9, pp. 187-190.

Merrill, A. L. and Watt, B. K. (1973), Energy Value of Foods: Basis and derivation, Agricultural Handbook No. 74, Human Nutrition Research Branch, Agricultural Research Service, U.S. Dept. of Agriculture, Washington, DC, USA.

Mrabet, A., Ferchichi, A., Chaira, N., Ben Salah M., Baaziz, M., ThreteadgillMrabet, P. (2008), "Physicochemical characteristics and total quality of date palm varieties grown in southern of Tunisia", Pakistan Journal of Biological Sciences, Vol. 11 pp. 1003-1008.

Nasseri, A. T., Rasoul-Amini, S., Morowvat, M. H. and Ghasemi, Y., (2011), "Single cell protein: production and process", American Journal of Food Technology, Vol. 6, 103-116.

Onishi, H. (1963), "Osmophilic yeasts", Advances in Food Research, Vol. 12, pp. 5394.

Pacheco, M. T., Caballero-Cordoba, G. M. and Sgarbieri, V.C. (1997), "Composition and nutritive value of yeast biomass and yeast protein concentrates", Journal of Nutritional Science and Vitaminology, Vol. 43, pp. 610-612.

Pramanik, K. (2003), "Parametric studies on batch alcohol fermentation using Saccharomyces yeast extracted from toddy", Journal of the Chinese
Institute of Chemical Engineers, Vol. 34, pp. 487-492.

Rahman, M. S., Kasapis, S., Al-Kharusi, N. S. Z., Al-Marhubi, I. M. and Khan, J. A. (2007), "Composition characteristics and thermal transition of date pits powders", Journal of Food Engineering, Vol. 80, pp. 110.

Rajoka, M. I. (2004), "Influence of various fermentation variables on exoglucanase production in Cellulomonas flavigena", Electronic Journal of Biotechnology, Vol. 7 No. 3, pp. 259-265.

Rajoka, M. I., Khan, S. H., Jabba, M. A., Awan, M. S. and Hashmi, A. S. (2006), "Kinetics of batch single cell protein production from rice polishing Candida utilis in continuously aerated tank reactors", Bioresource Technology, Vol. 97, 1934-1941.

Roels, J. A. (1983), Energetics and kinetics in biotechnology, Elsevier, USA.

Shalabia, S. E. (2011), "Bioactive constituents of Atriplex halimus plant", Journal of Natural Products, Vol. 4, pp. 25-41.

Shubbar, B. H. (1981), "Sugar extraction from dates", Date Palm Journal, Vol. 1 No. 1, pp. 61-78.

White, J. (1954), Yeast technology. Champan and Hall, London, United Kingdom. 